\title{
SACRED NATURAL PLACES OF ESTONIA: REGIONAL ASPECTS
}

\author{
Heiki Valk
}

\begin{abstract}
The article discusses the sacred natural places of Estonia from a regional perspective, outlining the two main regions - sea-oriented and inland. Regionality is most clearly expressed in the distribution of hiis sites - a phenomenon characteristic of sea-related areas. There are also other phenomena bound with specific areas, such as the distribution of natural healing places, farmstead offering places, natural offering places related to the cult of Tõnis/ Tennüs and cross-signed trees. The Orthodox Setomaa region is a distinctive area due to confessional and cultural factors. Besides presenting a general survey of the sources, the article also touches upon the reasons for the emergence of regional differences, outlining geographical, historical, and confessional factors. Regional differences in sacred natural places greatly correspond to other regional peculiarities which can be observed in the traditional popular culture.
\end{abstract}

Key words: history, popular culture, regional differences, sacred natural places

Sacred natural places exist in different parts of the world and have generally much in common (Bradley 2000: 14-32). The concept of sacredness can be connected with most different natural objects: trees, groves, forests, boulders, rocks, stones, caves, springs, rivers, lakes, etc. depending on the local natural conditions in the area. In form and functions the sacred natural places are greatly similar in the whole Eastern Baltic area and such is the situation also within Estonia: sacred trees, stones, and springs are widespread all over the country.

When investigating deeper into this seeming uniformity, however, a far more diverse picture with more or less clearly expressed regional peculiarities can be observed. In spite of its small area, the territory of Estonia is not homogeneous in character. Regional differences exist both concerning the appearance of the sacred natural places, as well as in their meanings, names and related traditions. These differences are not of random origin and character but are conditioned by certain geographical and natural preconditions, as well as by historical, cultural, and religious factors. The question of regional variations, however, has not deserved much special attention in former research. In the main general works on Estonian folk religion the sacred natural places 
have been treated from mainly phenomenological and conceptual aspects, and often not as a special topic but rather as phenomena related to some other questions (Eisen 1919, 1920; Loorits 1947, 1951, 1957; Paulson 1966; Masing 1995). However, to understand the cultural situation of the past also the aspect of regionality should be considered.

\section{NATURAL AND GEOGRAPHIC PRECONDITIONS}

Within Estonia there exists a big border zone, running from the northeast to the southwest, and separating the country into two major areas: the western, northern and central regions, on one hand, and southern Estonia, on the other.

This watershed can be observed in different contexts. First, it is reflected in geological conditions, physical geography and nature. Geologically, northern and western Estonia is based on limestone bedrock, while South Estonia is based on Devonian sandstone. The quantity and character of glacier-formed moraine formations on the bedrock also greatly vary. Western and northern Estonia are mainly flat, often with a most thin layer of soil upon the limestone bedrock. In southern Estonia the sandstone is covered by thick layers of sand, gravel, and moraine clay which form the material of Sakala, Haanja, Karula, and Otepää uplands, as well as of the drumlins of Vooremaa area (northern Tartumaa). The number of granite boulders, dropped down by the glaciers, is much larger in northern and western Estonia than in the southern and eastern regions, although natural boulders can be found everywhere.

In addition to geological and geomorphological differences, Estonia is divided into two major regions also by a zone of large forests, swamps and bogs, unsuitable for living (Fig. 1: 2, 3). This buffer zone divides Estonia into the 'maritime', that is northern and western, and 'continental', that is southern parts. The border is most clear in southwestern Estonia where large bogs and forests separate inland from the sea-related areas. Communication between the northern parishes of Viljandimaa and Järvamaa is possible only through a quite narrow passage; another natural border towards the south is the Navesti River. There are large swampy lowlands north of Lake Võrtsjärv, forming the bottom of post-glacial lake. Tartumaa district is presently separated from Virumaa and Järvamaa by a ten to fifteen kilometres wide zone of forests.

The natural borderline within Estonia greatly coincides with the main border in Estonia's historical geography. The territory of continental Estonia has been regarded since the crusaders' conquest in the 13th century as consisting of two major areas: 'Estonia proper' (Estland, Eestimaa) and Livonia (Livland, Liivimaa) or, more correctly, the northern part of the latter (the southern part 


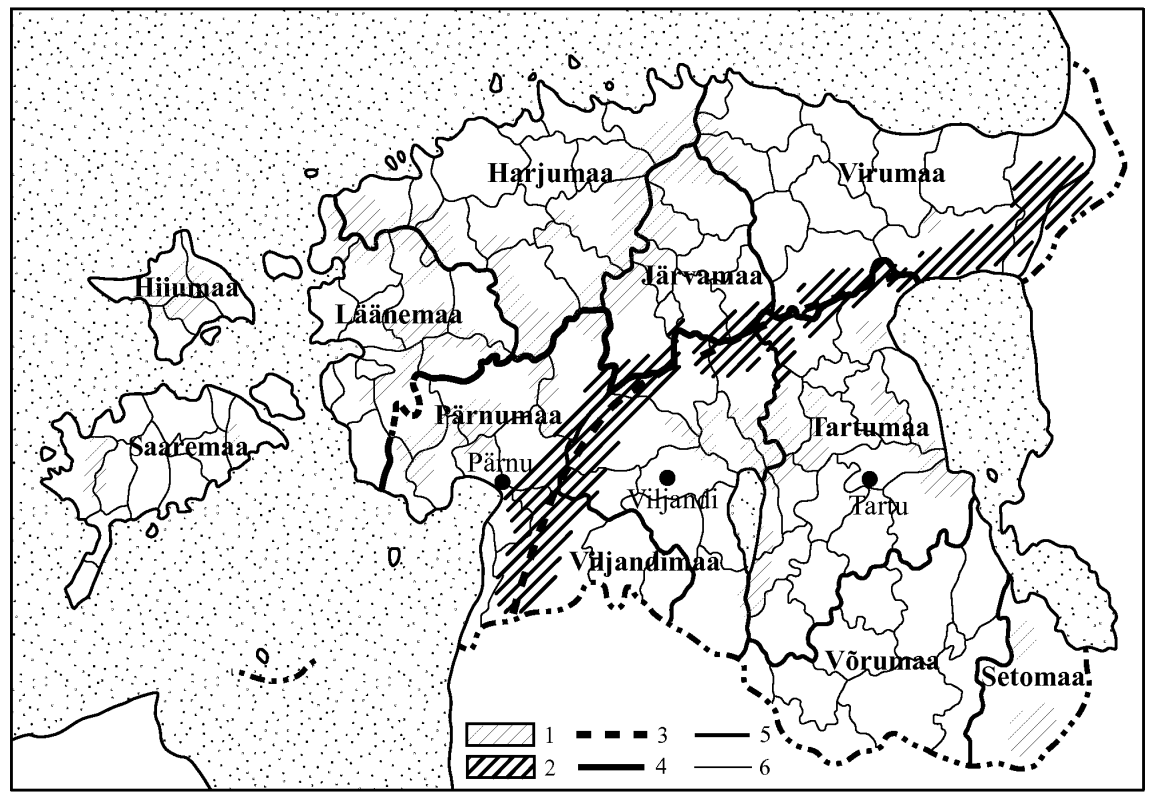

Figure 1. The main cultural border within Estonia and its natural preconditions: 1 - large uninhabited forest and bog areas; 2 - the uninhabited border area between sea-related and inland Estonia, 3 - the main cultural border between sea-related and inland Estonia; 4 - the border between the historical provinces of Estonia and Livonia; 5 - borders of 19th-century counties; 6 - parish borders.

of the historical province Livonia occupies present-day Latvia). The big differences in landscape, in combination with the presence of the natural uninhabited border zone between the two areas were also evidently the reason, why Estonia, in spite of the use of similar Finnic language(s), was perceived by the colonists to consist of two different countries. These two macro-areas also greatly correspond to the historical administrative division of Estonia, as reflected since the 17th century by the official border of the provinces of Estonia and Livonia, as well as by the administrative borders of the 19th and 20th centuries (Fig. 1: 4-6). Only the historical county of Pärnumaa (in its borders which existed until the administrative reforms of the late 1940s) is based on two different macro-areas. The formation of this county is conditioned not by geographic borders but by the presence of town and castle of Pärnu in its central part. Although 'maritime' Estonia cannot be regarded as a homogenous areathere also exist natural borders between the districts - the ethnographic borders within most of its continental part seem to be much smaller than between the 'sea-related' and 'southern' districts, especially southeastern Estonia (Viires 2008: 450-452). 
In spite of the fact that in terms of nature geography and rural livelihood, closely related to natural conditions, Estonia has traditionally been divided into Upland and Lowland Estonia (Kant 1935), such principle of division is not most suitable in terms of cultural history. An alternative and a more proper starting point, when speaking in cultural terms, would be to regard separately the sea-related and the inland, or 'northern' and 'southern' Estonia. The latter region which corresponds to the present-day Jõgeva, Tartu, Võru, Põlva, Valga and Viljandi counties is perceived as one area also in the common popular consciousness about the inner division of Estonia. The idea of cultural differences that do not correspond the nature geographic ones has recently been expressed also in human geography where some differences between the areas of two historical provinces, mainly in the context of the 18th-20th centuries, have been discussed (Pae 2008).

Cultural dissimilarities between the two large macro-areas can be observed also within the context of traditional popular culture of the 19th century whereby southern Estonia was more conservative than the "northern" areas (Viires 2008: 451-452). As the three largest regions, western, northern and southern Estonia have been distinguished in the traditional popular culture of Estonia,

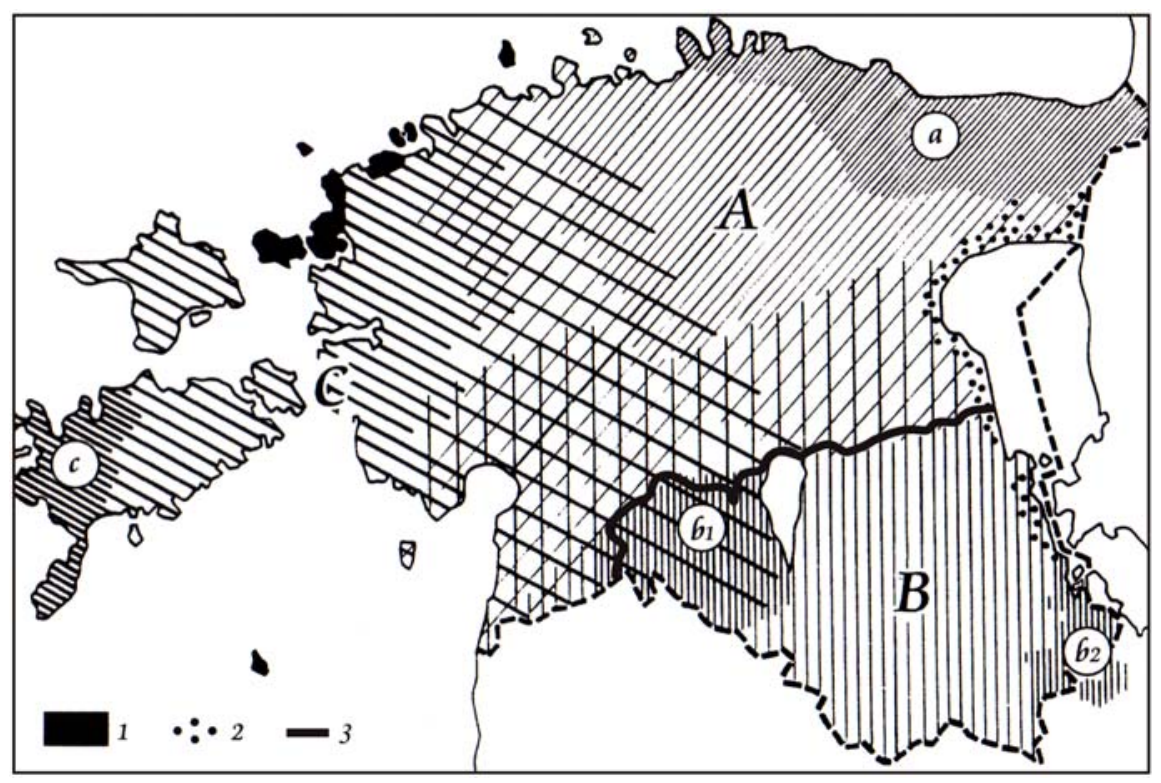

Figure 2. The main cultural regions within Estonian traditional popular culture (after Viires 2008, Map on p. 452). 1 - Swedish villages of coastal Estonia; 2 - Russian OldBelievers; 3 - the northern border of the South-Estonian dialect (after Pajusalu et al. 2002). A - North Estonia; B - South Estonia; C - West Estonia; a - coastal zone of Northeast Estonia; $b_{1}-$ Mulgimaa region; $b_{2}-$ Setomaa region; $c$ - western Saaremaa. 
whereas within the last-mentioned one the specific areas of Mulgimaa and Setomaa have been outlined (Fig. 2). Regional dissimilarities are big in folklore (Tampere 1956) and ethnology, such as in terms of main tools of land cultivation (Pärdi 2008: 85), food (Troska \& Viires 2008: 268), etc.

Differences within Estonia are also clearly expressed in language: the southern, that is Mulgi, Tartu and Võru dialects differ greatly from the North- and West-Estonian ones (Saareste 1932: 22-30; Kask 1956; Pajusalu et al. 2002: 46-60, 73-80; maps 1.3, 3.4, 5.1), whereas the border of southern Estonian dialect is quite clearly expressed (Fig. 2: 3). The difference is so large that speakers of the written language, which is based on the central dialect of northern Estonia, cannot understand the language spoken in the southeast.

Also the mentality of the people in the southeastern corner of Estonia greatly differs from that in the sea-related districts. In most general terms, the 'maritime' people are more reserved, unapproachable and introverted in character, whereas people of southeastern Estonia are more open and communicative. In spite of the fact that the regional ethno-psychological differences have not been thoroughly studied yet, but have been discussed only in general terms, ${ }^{1}$ they are clearly expressed in practical communication, ${ }^{2}$ as well as in folk narrative texts. These are, as a rule, short and dry in style in sea-related areas, but longer and more emotional in the southeast (Remmel \& Valk: in press), although some regional exceptions, expressed at the level of certain parishes (e.g., Kuusalu in the north), can also be observed. Also Saaremaa and Muhu islands seem to be in the context of popular mentality somewhat more 'southern' than western continental Estonia.

Between 'the proper north' and 'the proper south' there also exists a transition zone in terms of traditional popular culture. Tartumaa is broadly divided into a northern and a southern part by the Emajõgi River (the Tartu-Maarja parish north of the river is still considered to belong to southern Estonia). The northern part of Tartumaa forms a transitional area between northern Estonia and 'proper' southern Estonia, that is, between Virumaa and southeastern Estonia. A similar transitional area can be observed in the northern part of Viljandimaa district - north of the parishes of Halliste, Paistu, and Tarvastu. Among the reasons for the emergence of these transitional areas are also definite natural borders (Fig. 1: 1 see p. 47) which have hindered communication in the course of time.

The borderline between the two large macro-areas becomes visible also in case of sacred natural places. 


\section{SEA-RELATED AREAS: WESTERN AND NORTHERN ESTONIA}

Common features of the sea-related regions are expressed most clearly in the distribution of the word hiis, which is bound to the concept of sacredness in the context of sacred natural places (Eisen 1919: 239-244, Eisen 1920: 48-56, Loorits 1932a: 156-160, Loorits 1957: 11-21, Koski 1969, Remmel 1998, Jonuks 2007) - those of most different character and appearance. This word is known to have different meanings, which are in one way or the other associated with sacredness also in other Finnic areas: Finland, Aunus-Karelia and Ingermanland (Koski 1969 [1970]).

The distribution of hiis places is unequal in Estonia. This fact was first noted by Oskar Loorits (1932a: 151-152) and it has been outlined also in later research (Koski 1967: 86-92, Map 2; Jonuks 2007, Fig. 3). The authentic distribution area of the word involves only the Saaremaa Island, the historical Läänemaa, Harjumaa, Virumaa, and Järvamaa districts, as well as the western, 'maritime' part of Pärnumaa (Fig. 3: 2). The northern parts of Tartumaa and Viljandimaa districts (Fig. 3: 3) can be regarded as a transitional zone and the toponym is almost missing in Mulgimaa area. In southeastern Estonia, its sporadic authentic presence can be suggested only in rare cases in the south-

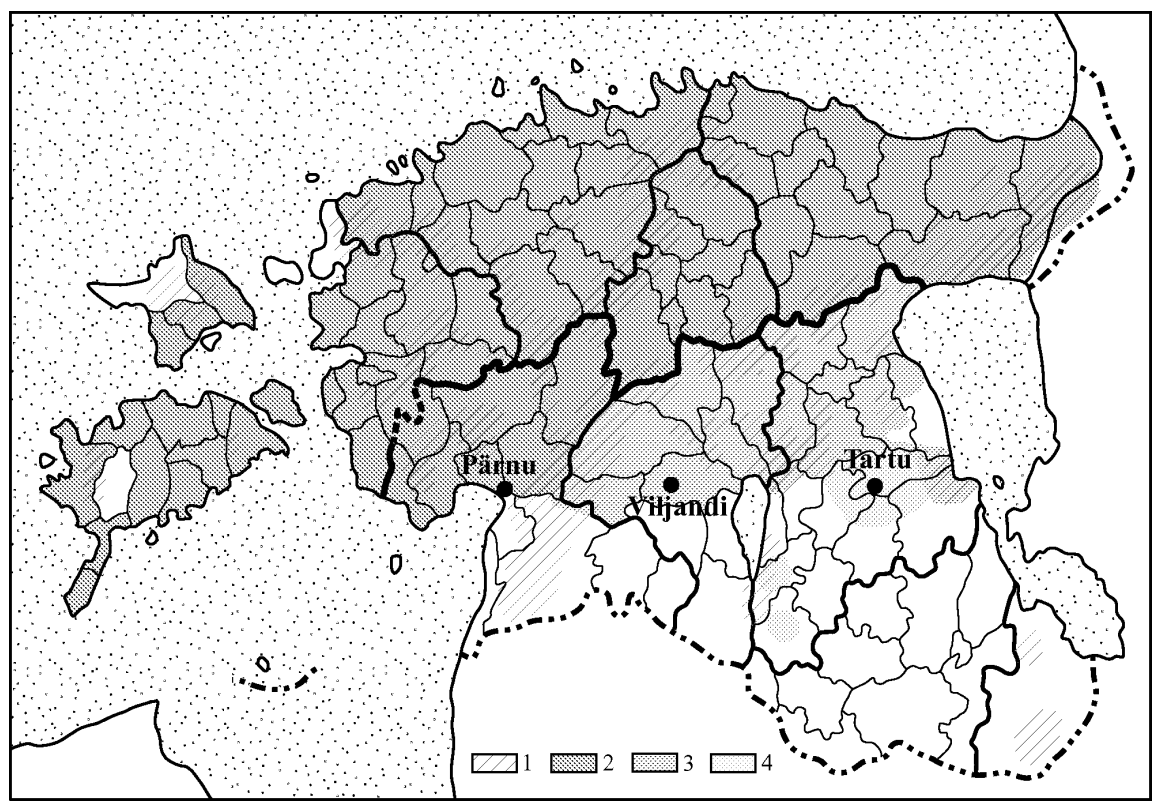

Figure 3. The distribution of hiis sites in Estonia. 1 - the main natural border of sea-related and inland areas; 2 - the main area of authentic hiis toponyms; 3 - the peripheral occurrence of authentic hiis toponyms; 4 - the sporadic occurrence of authentic hiis toponyms. 
ern part of Tartumaa (Fig. 3: 4) as a phenomenon representing the periphery of the transitional zone. From Võrumaa and the Seto region, however, authentic data of its presence seem to be missing. In this area, hiis can be regarded as a late innovation which emerged only in the second half of the 19th century. In the context of National Romanticism and emerging nationalism of that time, hiis, meaning 'a sacred grove', became a mental symbol of national identity, and the word was introduced also in these areas where it was formerly unknown. The meaning of a symbol of national identity was preserved and confirmed in the period of the national state in Estonia in the 1920s and 1930s (Remmel 1998: 48-49).

The etymology of the word hiis is largely unclear (Jonuks 2007: 15-16), and so is its former meaning in its authentic distribution area, that is, within the sea-related districts of Estonia. The word designates not only groves, but exists in highly different combinations, being related also to stones, springs, depressions, hills, fields, etc. Occurrence of the term for most different natural objects refers, most likely, to some common features characteristic of all of them. Since the word hiis does not feature in the compound names of all sacred natural places of the sea-related macro-region, it seems to designate not sacredness in general, but some more specific aspects of it. Probably, the use of the word hiis might not be conditioned by some external features of the hiis sites. Instead, the reason might be hidden in some specific inner, probably energetic qualities of such places, perceived by prehistoric and medieval people (Valk 2007). Thus, being attributed to different objects in the Estonian context the word $(h)$ iie, when being an initial element of compound place names, seems to function as an adjective rather than a noun.

Another specific feature which is characteristic of the sea-related areas is the large number of single trees and stones, the functions of which are limited to healing practices and related gift-giving. No other sacral or magical practices that serve more general purposes - luck, welfare, getting help in the most general sense - can be related to these sites. While using springs for healing purposes was practiced in all Estonia, the distribution of trees and stones with merely healing qualities is limited mainly to the western part of Estonia, except for the western part of the island of Saaremaa (Fig. 4: 1 see p. 54). The eastern border of their distribution area is largely determined by the uninhabited zone which stretches from the southwestern corner of Estonia to the border of Harjumaa and Virumaa in North Estonia. It seems that also the share of multi-functional healing springs, namely those which were used for treating different kinds of illnesses rather than a specific disease, is larger in this region than the average elsewhere in Estonia. 
Although the practice of healing eyes with spring water and respective toponyms (Silmaallikas in northern and western dialects; Silmäläte in the southern dialect) are known all over Estonia, in West Estonia, the functions of natural healing places are often reflected in other specific toponyms or popular names of the sites, such as maa-aluste kivi or moaljakivi, that is "stone of the 'underground"'. Maa-alused or moaljad designates both an underground fairyfolk, as well as a specific kind of skin disease, which was believed to have been caught by touching the ground (Loorits 1957: 76-79). For example, the Muhu island is known to have a large proportion of healing sites among the sacred natural places of western Estonia, as well as their specific features (Sirp 2001: 38-47). The names Arstikivi and Tohtrikivi, as well as Arsti- or Tohtriallikas, referring respectively to stones or springs with healing qualities, have been derived from the German loanword 'doctor' (Arzt; Töchter). Such names are evidently of rather late origin, coming from times when doctors as medical specialists became known in the native peasant society. These toponyms give evidence of the big importance of the regional borders in communication even in quite recent times.

The function of magical rites in natural healing places is not so much communication with supernatural beings: it is rather treating a disease with the help of the place or object - a tree, spring, or grove itself. The general principle of gift-giving and performing magical rites was also practiced but the gifts, as known from folkloric sources and ethnographic evidence, are usually just smallvalue coins or unwanted waste - strips of cloth, pieces of iron, horse-shoes, nails, glass, etc. It is characteristic that no food was laid upon the healing places as gifts for healing. For healing purposes the principle of contact magic was often applied, that is, the disease was transferred by means of a strip of cloth or some artefact which had been in touch with it, rather than "real" offering or gift-giving was practised.

Natural healing places (or objects) exist in the West-Estonian region in parallel to sacred places of higher "rank" or quality, those used in religious and ritual practices for more general purposes. It is characteristic that healing places are often not designated with the word hiis and that they are usually located outside the hiis areas also on the landscape.

Visiting the healing places was, unlike communication with "real" offering places, that is, those places where offering was made for more general purposes, not an act of permanent character: the sites were visited occasionally, in case of emergency, as if paying a visit to the doctor. At these places, the concept of sacredness is not connected with the territory around them, but is limited to the natural objects themselves. The healing places, being less multifunctional, were also regarded somehow "weaker" than the sacred places of 
more general character. As a rule, sacrilege and breaking taboos there do not lead to supernatural punishment. Differently from them, sacred sites of "higher level", as well as cemeteries, are often related to the principle of punishment for sacrilege. The only exception is punishment for taking gifts (e.g., coins) brought to the healing places by others: this may lead to illness.

\section{INLAND AREAS: SOUTHERN ESTONIA}

Differently from the North and the West, in South Estonia the word hiis is missing in the authentic tradition. In this region, sacredness is not so clearly expressed in words (sometimes through the word püha/pühä 'sacred') but mainly in ritual practices - offering, gift-giving, following prohibitions and taboos. This difference, evidently, rises from linguistic reasons: the word hiis is missing in the South-Estonian dialects and the concepts expressed by it in northern and western Estonia were not designated by a common term there at all.

The missing of the word hiis is, however, not only a linguistic problem. Also the sacred natural places of southern Estonia are not as "homogeneous" as the hiis areas in the north and west. While hiis is a concept often bound to certain territories which may involve different objects, the "territorial" character of sacred natural places is not so clearly expressed in southern Estonia - at least, not on the terminological level. While the concept of sacredness is often associated with larger areas (a grove or forest) in the authentic distribution area of the word hiis, in southern Estonia it is mainly associated with single objects (trees, stones, and springs), and sacred complexes are rare, as a rule.

Regional differences in the tradition about sacred natural places also vary depending on the character of the settlement pattern. In northern and western Estonia, that is, in areas with definite villages and village communities, the sacred natural places are associated with specific villages in the oral tradition. In South-Estonian areas with a more dispersed settlement pattern, however, they are often presented as being connected to a single farmstead.

Especially clearly are such connections expressed in the historical/ethnocultural Mulgimaa area, southern part of the Viljandimaa district, where the identity of single farms is strongly stressed in the traditional popular culture. The idea of farmstead offering sites (Fig. 4: 2; Loorits 1935) is especially clearly expressed in this area whereby differences between parishes can be also observed. In Tarvastu, the idea of farmstead offering places is expressed by the so-called ahikotus sites ( $a$ hi 'offering', kotus 'place' or 'site'). This general term designates offering places of different character: stone heaps (probably stone 
graves?), small enclosed areas/gardens, bushes, etc. In Halliste and Karksi parishes offering was carried out at sites called ohvriaed ('offering garden'/ 'enclosure)', that is small territories surrounded by fence; in Karksi also by stones called Pellikivi or Pel'ekivi, which were associated with the home spirit Pell. The same principle concerns the sacred trees. In Karksi it was said that "each farmstead had its own [sacred] tree". Sacred natural objects (trees, stones), when enclosed, may have existed as a part of ohvriaed or ahikotus sites. It seems that in the Mulgimaa area, the main feature of the sacred natural places has been connected to a specific farmstead and that the watershed did not flow between different natural objects: trees, stones, groves, hills, etc.

Regional connections with a definite deity can be met also in Võrumaa and southern Tartumaa. Sometimes the name Tõnis, a derivation from the name of St Anthony, or Tennüs can be met there in connection with sacred natural places of the local level (Fig. 4: 3). It occurs both at the sites of Catholic chapels, as well as near trees and stones where gifts were brought to Tõnis or Tennüs on St Anthony's Day (January 17th) (Hiiemäe 2006: 100-107). After the destruction of Catholic chapels in the wars of 1558-1582 and 1601-1625 or as a

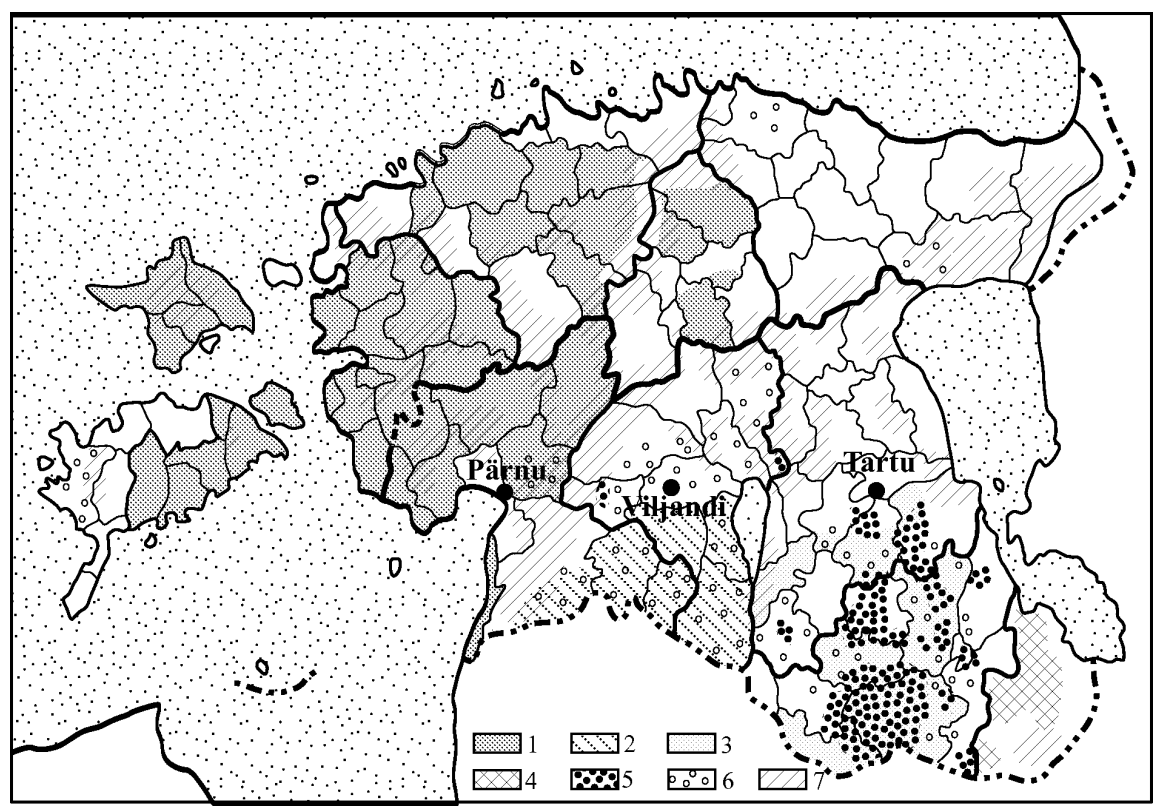

Figure 4. Regional phenomena in the sacred natural places of Estonia. 1 - the area of monofunctional natural healing places; 2 - farmstead offering sites in Mulgimaa region; 3 offering to the deity/saint Tõnis in natural places; 4 - Orthodox Seto region; 5 - the present area of the sacred cross-signed trees (after Kõivupuu 2009; with author's complements; 6 folkloric data about cross-signed trees in the past (after Kõivupuu 2009: 52-53); 7 - large uninhabited forest and bog areas. 
result of later activities of Lutheran authorities, these sites became the sacred natural places. The fact that other Christian saints are almost missing in the toponyms of the sacred natural places in Lutheran (former Catholic) areas of Estonia, gives evidence of the pre-Christian roots of the cult of Tõnis/Tennüs. Also the fact that the name of Tõnis appears notably often in the names of chapels at medieval village cemeteries (Valk 1995a: 461-462, 1995b: 503-504) indicates to his special status and the merging of a pre-Christian deity, who was probably worshipped in nature, with a Christian saint.

The cult of Tõnis in Võrumaa has been traditionally regarded as a part of the cult of Tõnn (Loorits 1932b: 47, Loorits 1951b: 309-311). The home deity Tõnn (Eisen 1933, Loorits 1951b: 309-313), known in the western part of continental Estonia, including Pärnumaa and most of Läänemaa, Harjumaa and Järvamaa, as well as the south Estonian Mulgimaa district, however, seems to be a different deity. Tõnn and Tõnis/Tennüs might rather be modifications of different beings of non-Christian origin (still maybe of somewhat common or related roots) than popular derivates of St Anthony, although both have also merged with the Christian saint. However, in case of Tennüs also a different etymology can be suggested. It might also reflect the act of thanking or thanksgiving (tennämä 'to thank' in Võru dialect) - one aspect of offering practices which has, merging with the Christian saint, obtained a personified status.

A special feature of southern Estonia is the role of specific trees in funeral rites. In Lutheran areas, the tradition is expressed by cutting a cross-sign in a tree trunk during the funeral procession: by making it the formerly ordinary trees are given a sacral meaning. The tradition of the so-called cross-signed trees (ristipuu) is still practised in Võrumaa but it existed in earlier times in larger areas (Torp-Kõivupuu 2003, Kõivupuu 2009). Although there exists sporadic data about cross-signed trees from North Estonia, the core area of the tradition is clearly the southern part of the country (Fig. 4: 5, 6). In the Orthodox Setomaa, the south-easternmost corner of the country, the idea of relating a tree with funeral rites is expressed in another form, in the concept of lautsipuu (see below).

\section{ORTHODOX SETO REGION}

Within southeastern Estonia, Setomaa is a distinctive area with a different historical background (Fig. 4: 4). As a result of the crusades of the 13th century and the formation of border between Medieval Livonia and Pskov (Selart 2002: 142-150), some areas with South-Estonian population remained in the domain of Russia. These border areas of the Pskov region where the indigenous Finnic 
inhabitants had preserved their identity became (together with some Russianpopulated regions) a part of the newly-born Republic of Estonia as a result of the Peace Treaty of Tartu in 1920. The native Finnic population in this area, the Setos, had been Orthodox since their Christianization. Owing to their isolation from the rest of Estonia, and the peripheral position, both in the context of Russia and Estonia, the Seto areas were highly conservative until the cultural innovations and forced Estonianization which started in the 1920s (Lõuna 2003).

The specific history of Setomaa is reflected also in terms of sacred natural places. Due to a different confessional background, this is the only area in Estonia where a syncretic combination of Christian and pre-Christian rites and beliefs can be observed in sacred natural places. The meeting and merging of traditions is most clearly expressed in the case of two sacred stones: Jaanikivi (St John's stone) in Miikse (Meeksi) and Annekivi (St Anne's stone) in Pelsi village (Inland 1860: 627; Wiedemann 1876: 411-412, 415-416; Truusmann 2002: 184-185; Loorits 1951b: 342-345; Valk 2008), both located in the periphery of Orthodox areas, close to the border of Livonia. In these cases, as well as in some others, for instance, in Härmä (Remmel 1996: 43-45) and Saatse villages ( $P G V 1864)$, a chapel was built at the sacred natural place, but in spite of this carrying out pre-Christian rites were continued. The blessing of sacred springs has also been part of the religious practices of the Orthodox Church both in the first half of the 20th century (Chernomorova 2005: 96-97), as well as nowadays. Thus, at the Epiphany of the Old Calendar (January 19th), Silmäläte 'the spring of eyes' is blessed annually in Värska and water is taken from there into the church. The well in the yard of the Pechory Monastery, in Seto tradition the Well of St Mary (Pühä-Maar'a kaiv), is broadly known for its healing qualities in the Russian Orthodox world. At Izborsk, the eastern part of the Seto region (since 1945 a part of Russia), some years ago even a natural spring called Slovenskiie Kliuchi without any recorded popular data of its former sacredness was blessed and re-named into the spring of Twelve Apostles (Chernomorova 2005: 97). In the Orthodox areas of Russia, connections between preChristian and Christian traditions can be observed also in rural sacral architecture of local level: here a continuous transition from pre-Christian cult houses to Orthodox village chapels can be observed (Orfinskii 1992). The stages and expressions of this development can be met also in the Seto village chapels.

It is characteristic that the combination of the sacred natural places and the names of saints is almost missing in Lutheran Estonia (Valk 2004: 304307), where their popular names are "non-Christian", referring often to some specific features or functions of the site, but not to the names of Catholic saints. As the names of saints are sometimes recalled in connection with the sites of 
former Catholic chapels in Estonia (Vahtre 1989), this difference evidently shows that in most of Estonia the sacred natural places were not "Christianized" in the Catholic period. However, the combination of chapel and church toponyms frequently occur in case of cemeteries and also prehistoric stone graves in Estonia, but not concerning sacred natural places.

A specific feature of the Setomaa area is the lautsipuu tradition. The word designates an old tree, often a pine, which was located at the village border and was used for disposal of things which had been in contact with the corpse - straw and the board (lautsi) on which the body was kept before the funerals, as well as the vessels, soap and whisks used for washing it. Lautsipuu was also a border sign, bound to the concept of liminality: on the way to the cemetery the whole village escorted the corpse up to the tree. Although the concept of sacredness is not directly expressed in the toponyms, it is clearly reflected in attitudes to these trees. The tradition of lautsipuu is in no ways bound to Orthodox Christianity. Evidently, it represents some old ethno-cultural border between Võrumaa and Setomaa, originating already in pre-Christian times.

\section{HISTORICAL ASPECTS OF REGIONAL DIFFERENCES}

Regional variations in the character and names of sacred natural places have been influenced and caused far more by historical factors than by the natural background. The first group among them includes the historical communication orientations of different regions, as well as communication borders between them, greatly caused or facilitated by natural preconditions. The searelated regions have historically faced the Baltic Sea: communication was oriented towards Scandinavia, mainly Gotland and the coastal areas of continental Sweden, but the historical contacts with southwestern Finland should not be forgotten either. In this context it seems natural that the sacred natural places of coastal areas reflect common features with other territories, which are bound with them by the sea, as reflected, for example, in the distribution of hiis(i) sites in Finland, Estonia, Karelia, and Ingermanland (Koski 1967, 1970). The second macro-area, that is, the inland districts have historically been continental-orientated. These lands, where people are more extraverted than in the seaside areas, have faced the south, towards northern Latvia, and the southeast, the Pskov region.

The specific features of regions have a significant historical dimension. The presence of the two macro-areas within Estonia can be observed clearly and continuously at least from the 1st millennium BC onward, when overseas contacts incorporated the seaside districts into the common cultural space of the 
coastal regions of the Baltic Sea. Maritime orientation has lead to the introduction of stone graves, cup-marked stones and the earliest farming, represented in the early field systems (Lang 2007: 95-105, Tvauri 1997, 1999). Differences between the two macro-areas can be observed in archaeological records also in the Roman Iron Age (1st-5th century) (EEA 1982: 243-246, Table XIV) and later prehistory, as well as in medieval and early modern times (e.g., Valk 2001).

Innovations from the sea have reached southern Estonia with a temporal delay and indirectly, being intermediated by the seaside regions. Contacts with the east, historical Novgorod and Pskov Lands, were partly hindered by the big lakes - Lake Peipsi and Lake Pskov - but they still existed north and south of this big natural border. Towards the south from the present-day southern Estonia, in the Latvian direction, there has been no clear natural border between the Finnic and Baltic population at least since the end of the Roman Iron Age. The Baltic population gradually intruded into the former Finnic environment - this development was especially extensive due to the Latgallian expansion in the 8th-10th century (Radinš 2006) - and step-by-step assimilated the Finnic substrate population; this process has lasted until recent times. Natural preconditions for the formation of the present-day Estonian-Latvian state border (agreed in the early 1920s) are not more favourable than in case of inside borders, those between the different districts of Estonia.

As the second group of reasons for regional differences, also those arising from the ecclesiastical context and church history must be noted. During the Christian period, also confessional factors may have largely formed the ecclesiastical attitudes towards popular practices at sacred natural places. As mentioned above, the attitudes of the Eastern and the Western Church have been widely different. The latter, at least according to the Estonian source material, has expressed a negative attitude in the question of involving sacred natural places in the Christian context. The Orthodox Church has practiced, on the contrary, the policy of positive occupation and examples of such practices can be found also in the context of Russia (Panchenko 1998). It should be noted that most often 'positive occupation' takes place by mediation of saints - namely, by relating a natural object to a definite saint. On the first glimpse, the reasons of the different approaches to the ecclesiastical sanctification of sacred natural places may be connected with different confessional attitudes towards the saints: the Lutheran Church regards them only from a historical perspective, but the Orthodox Church views them as real and acting powers. In fact, the reasons of the watershed seem to be deeper: as mentioned above, in Livonia a negative attitude towards the blessing of sacred natural places existed already in the Catholic Period. Concerning southern Estonia, also the later 
Lutheranization of the area should not be forgotten: unlike northern and western Estonia which were involved in the Lutheran Church since the end of the Livonian War (the early 1580s), South Estonia became Lutheran only after the area was transferred from Catholic Poland to Lutheran Sweden, de jure only as a result of the Truce of Altmark in 1629.

Thirdly - political and administrative borders also may have favoured or hindered communication, directing the orientation of population in one or another direction, that is, towards different centres. The presence of regional differences might be expected already within medieval Livonia where borders may have existed at different levels. First there was a border between northern Estonia, subordinated to Denmark, and the rest of the country; second between different medieval bishoprics, as well as between the bishops' territories and the areas of the Livonian Order.

It must also be considered that the differences in the density of network of known sacred natural places may be of rather late origin, caused by the different rate at which the tradition disappeared in different regions. A decisive factor here was the wave of religious awakening, which was invoked by the activities of the Moravian brothers since the late 1720s and 1730s. The spread of new ideas and a change in mentality (Põldmäe 1935; Ilja 1995, 2002) brought along, at least in some regions, also the destruction of sacred natural places. Such activities have been noted, for example, in Urvaste parish, Võrumaa district - an area which can be regarded as the most "pagan" in the 17th century. It was namely in this parish where the last pagan revolt occurred: in 1642, the local peasants destroyed the newly-built mill on the sacred Võhandu River which was considered to be the residence of the Thunder (Gutslaff 1644). In the same Urvaste parish, 60-80 sacred natural places were destroyed by peasants who had joined the Moravian Brethren's movement in the 1730s (Ilja 2002: 27$){ }^{3}$

A systematic overview of the impact of the Moravian Brethren movement upon the sacred natural places is still waiting to be written: for this, first, a complete mapping of the sacred natural places is needed. There may have existed also regional differences in the activities of different communities of 'the brethren' and/or 'the awoken people'. Thus, in Läänemaa, West Estonia, the number of sacred natural places is large, in spite of the wide spread of the awakening movements of the 18th and 19th century (Plaat 2001). From Virumaa in Northeast Estonia there is data about a 'heaven-goer' who was taken to the heavens by an angel when sleeping at an old offering stone, which was regarded as 'a place of power' by the local people (Põldmäe 1935: 136).

As a factor from quite recent history, also regional differences in popular education in the 19th century may have influenced the process of the natural 
sacred places being forgotten. In this context, also the centre-periphery perspective in the location of the regions should be taken into account. The longer persistence of the tradition in the Setomaa, which existed in isolation from the rest of Estonia until the 1920s, is closely connected with the fact that the first schools were founded there only at the end of the 19th century. The islands are also a peripheral region and thus, on the Muhu Island 34 formerly unknown sacred natural places, not recorded in archaeological or folklore archives, were discovered by interviewing the local inhabitants during fieldwork conducted in the area in 2005 and 2006 (Kaasik 2007: 45).

It must also be noted that the situation of the sacred natural places in the areas inhabited by historical ethnic minorities - the coastal Swedes and Russian Old-Believers on the western coast of Lake Peipsi - differs much from that in the rest of Estonia. In the villages of Old-Believers there is no data of sacred natural places and among the coastal Swedes data is available only about healing springs.

When discussing the distribution maps of sites, also the representativity of the source material in the archaeological and folklore collections must be taken into consideration: data from different regions have not been evenly recorded.

\section{PERSPECTIVES FOR FURTHER STUDIES}

As sacred natural places are a widespread phenomenon, understanding them requires a transnational approach, especially in common border areas. The study of hiis(i) sites which has been carried out in Estonia, western Finland, Karelian Isthmus and Ingermanland, that is, on the territories of Finland, Russia and Estonia (Koski 1967, 1970) is a good example of transnational approach to the topic. Comparative research has been conducted into the topic of cup-marked stones (Tvauri 1997: 22-23; 1999: 120-121, 143-149). In fact, other kinds of sacred natural places in sea-related regions of Estonia have attracted no research interest in a broader geographical context. Situating the data from Estonian coastal regions against a broader background is also hindered by the limited amount of research work done in Scandinavia where the study of sacred natural places based on folkloric and ethnographic data has belonged to the realm of local studies rather than of professional research. The latter has concentrated mainly on the study of toponyms (e.g., Brink 1990, 2001; Vikstrand 2001).

From the Estonian viewpoint, the transnational aspects in the study of sacred natural places have been even more neglected in terms of the southern regions - both in the Latvian and Russian direction. The real differences be- 
tween the sacred natural places in southern Estonia and northern Latvia which were not separated from each other by a political border from the 13 th century to 1917 might be expected to be much smaller than suggested. As the population of both areas is based on a Finnic substrate, the main differences might be not of 'national' but merely of linguistic character and maybe also of rather late origin. Proving or disproving this hypothesis needs, however, a profound and comprehensive study of the source material in the framework of some joint research project.

As a whole, the questions of 'transnational' character of definite phenomena should be strongly considered in the study of sacred natural places - both within research limited to one country, as well as in the context of inter- or transnational studies. For understanding essential differences between regions, the political and administrative borders of the 19th and 20th century should be forgotten: in fact, they can be used only as tools for describing the geographic location of sites. Regarding single phenomena merely in the context of these borders might be harmful for the results of the research, since present-day political and ethno-cultural realities may not correspond to the former ones. Adjacent territories, located close to any researcher's turf, should by no means be forgotten in further studies - this may hold the key to the local peculiarities.

\section{CONCLUSIONS}

Regional differences in the distribution and character of sacred natural places are not occasional phenomena of individual character, but a manifestation of broader regional identities. The main regions of sacred natural places, as outlined in Estonia (Fig. 3 see page 50, Fig. 4 see page 54), largely correspond to the main areas of traditional popular culture - northern, western and southern Estonia (Fig. 2 see page 48) - which have been distinguished as a result of comprehensive analysis of the ethnographic data. Thus, on the most general level, hiis sites (like prehistoric cup-marked stones) are common to the districts of northern and western Estonia, but specific healing places are characteristic of the West-Estonian region. They both, however, are alien to southern Estonia. As in other aspects of traditional culture, Mulgimaa, Setomaa, and western Saaremaa regions emerge also in terms of sacred natural places as separate sub-regions. Like in popular culture in general, in terms of sacred places there also exists a transitional zone between the sea-related and inland districts. 
The regional dissimilarities of sacred natural places and the related tradition is a fact which has been greatly overlooked in former research. Bigger borders exist mainly in larger areas, unsuitable for living and communication. Regional differences in tradition have also been caused by definite historical factors, among which traditions and orientations of communication should be stressed. In prehistoric times, they were greatly influenced or caused by geographic and natural conditions, in medieval and later times also by political and religious borders. Both a historical and source-critical approach is needed for analysing the regional differences in sacred natural places: the sites should be regarded in the context of the time of their functioning, considering the general archaeological background, historical and religious situation, the representativity of data, as well as the rate at which the tradition has disappeared in different regions since the 19th century.

This article has outlined only superficially some aspects of the topic, raising questions rather than giving answers. A more profound study into the regional aspects of sacred natural places, expectedly both on a more local and transnational level, is a task for future research.

\section{ACKNOWLEDGEMENTS}

This research was supported by the European Union through the European Regional Development Fund (Center of Excellence CECT) and by Estonian Science Foundation grant No. 6119.

\section{NOTES}

1 The topic of regional differences in popular mind has not attracted much attention from researchers. Although Oskar Loorits repeatedly tried to outline the common features of the Estonian national mentality as a whole, as well as to find out the historical roots of its peculiarities (e.g., Loorits 1932b: 105-110, 1951a), at regionally more local levels the topic has been raised only lately (Pae 2008: 85-87).

${ }^{2}$ According to the author's personal experience gained in the course of archaeological field inventories in different parts of Estonia.

3 Until now, data about 25 sacred trees, groves, stones and springs or their sites have been recorded from Urvaste parish and held in the Estonian archaeological and folklore archives. 


\section{REFERENCES}

Bradley, Richard 2000. An Archaeology of Natural Places. London \& New York: Routledge. Brink, Stefan 1990. Cult Sites in Northern Sweden. In: T. Ahlbäck (ed). Old Norse and Finnish Religions and Cultic Place Names. Papers delivered at the Symposium Encounters between Religions in Old Nordic Times and Cultic Place Names held at Åbo, Finland, 19-21 August 1987, pp. 458-489.

Brink, Stefan 2001. Mythologizing Landscape. Place and Space of Cult and Myth. In: M. von Stausberg (ed.) Kontinuitäten und Brüche in der Religionsgeschichte. Festschrift für Anders Hultgård zu seinem 65. Geburtstag am 23.12.2001. Berlin \& New York: Walter de Gruyter, pp. 76-112.

Chernomorova, Alena A. 2005. Izborskie rodniki: predaniia, obychai i traditsii. In: Izborsk: istoriia $i$ sovremennost'. [The Springs of Izborsk: Legends, Customs and Traditions.] Izborsk: Muzei-zapovednik "Izborsk", pp. 95-98.

EEA 1982 = Jaanits, Lembit; Laul, Silvia; Lõugas, Vello \& Tõnisson, Evald (eds.) 1982. Eesti esiajalugu. [Prehistory of Estonia.] Tallinn: Eesti Raamat.

Eisen, Matthias Johann 1919. Eesti mütoloogia. [Estonian Mythology.] Tartu: Eestimaa Kooliõpetajate Vastastikuse Abiandmise Seltsi raamatukaupluse kirjastus.

Eisen, Matthias Johann 1920. Esivanemate ohverdamised. [The Offerings of Ancestors.] Tallinn: Varrak.

Eisen, Matthias Johann 1933. Vändra Tõnn 1932. a. teadete valgustusel. [The Tõnn of Vändra in the Light of Records from 1932.] Usuteadusline Ajakiri, lisavihk nr 4. Tartu: Akadeemiline Usuteadlaste Selts.

Gutslaff, Johann 1644. Kurtzer Bericht und Unterricht von der Falsch-heilig genandten Bäche in Lieffland Wöhhanda. Daraus die Unchristliche Abbrennunge der Sommerpahlschen Mühlen geschehen ist. Aus Christlichem Eyfer, wegen des Unchristlichen und Heydnischen Aberglaubens gegeben von Johannes Gutslaff, Pomer. Pastorn zu Urbs in Lieffland. Dorpat: H. Ohm.

Hiiemäe, Mall 2006. "Päiv ei ole päiväle veli.” Lõuna-Eesti kalendripärimus. [SouthEstonian Folk Calendar Lore.] Tartu: Eesti Kirjandusmuuseumi Eesti Rahvaluule Arhiiv.

Ilja, Voldemar 1995. Vennastekoguduse (herrnhutluse) ajalugu Eestimaal (Põhja-Eesti) 1730-1743. [History of Moravian Brethren Congregation in Estonia (North Estonia), 1730-1743.] Tallinn: Logos.

Ilja, Voldemar 2002. Vennastekoguduse (herrnhutluse) ajaloost Liivimaal (Lõuna-Eesti) 1729-1750. III. [History of Moravian Brethren Congregation in Livonia (South Estonia) 1729-1750, Vol. 3.] Tallinn: Logos.

Inland 1860 = Das Inland: Eine Wochenschrift für Liv-, Esth- und Curländische Geschichte, Geographie, Statistik und Litteratur, No. 34.

Jonuks, Tõnno 2007. Holy Groves in Estonian Religion. Estonian Journal of Archaeo$\log y$, Vol. 11, No. 1, pp. 3-35.

Kaasik, Ahto 2007. Ajaloolised looduslikud pühapaigad - väärtused looduse ja kultuuri piirimail. [Historical Natural Sacred Places: Treasures on the Borders of Nature and Culture.] In: H. Valk (ed.) Looduslikud pühapaigad. Väärtused ja kaitse. Õpetatud Eesti Seltsi Toimetised, Vol. 36. Tartu: Õpetatud Eesti Selts, pp. 2374 . 
Kant, Edgar 1935. Bevölkerung und Lebensraum Estlands: ein anthropo-ökologischer Beitrag zur Kunde Baltoskandias. Tartu: Akadeemiline Kooperatiiv.

Kask, Arnold 1956. Eesti murrete kujunemisest ja rühmitumisest. [About the Formation and Groups of Estonian dialects.] In: H. Moora (ed.) Eesti rahva etnilisest ajaloost. Artiklite kogumik. Tallinn: Eesti Riiklik Kirjastus, pp. 24-40.

Koski, Mauno 1967. Itämerensuomalaisten kielten hiisi-sanue. Semanttinen tutkimus, 1. [The Finnic Word Hiisi. A Semantic Study, Vol. 1.] Turun Yliopiston Julkaisuja. Sarja C, Scripta lingua Fennica edita, 5. Turku: Turun yliopisto

Koski, Mauno 1970. Itämerensuomalaisten kielten hiisi-sanue. Semanttinen tutkimus, 2. [The Finnic Word Hiisi. A semantic study, Vol. 2]. Turun Yliopiston Julkaisuja. Sarja C, Scripta lingua Fennica edita, 7. Turku: Turun yliopisto

Kõivupuu, Marju 2009. Hinged puhkavad puudes. [Souls Rest in Trees.] Tallinn: Huma. Lang, Valter 2007. The Bronze and Early Iron Ages in Estonia. Estonian Archaeology, Vol. 3. Tartu.

Loorits, Oskar 1932a. Estnische Volksdichtung und Mythologie. Tartu: Akadeemiline kooperatiiv.

Loorits, Oskar 1932b. Vana eesti rahvausk. [Old Estonian Folk Religion]. Elav Teadus, 12. Tartu: Eesti Kirjanduse Seltsi kirjastus.

Loorits, Oskar 1935. Mulgimaa ohvrikohad. [Offering Sites in Mulgimaa Region.] In: Kaleviste mailt. Õpetatud Eesti Seltsi Kirjad, Vol. 3. Tartu: Õpetatud Eesti Selts, pp. 225-300.

Loorits, Oskar 1939. Muinas-Eesti unarussejäänd põhiseadusest. [On the Forgotten Constitution of Prehistoric Estonia.] Oma rada. Programmartikleid uue Eesti loomisel 1934-1938. Tallinn: Kuldkiri, pp. 119-138.

Loorits, Oskar 1951a. Eestluse elujõud. [The Vitality of Estonianism.] Stockholm: Tõrvik.

Loorits, Oskar 1947, 1951b, 1957. Grundzüge des Estnischen Volksglaubens. Skrifter utgivna av kungl. Gustav Adolfs Akademien för folklivsforskning 18: 1-3. Uppsala: Lundequistska Bokhandeln; Köpenhamn: Munksgaard.

Lõuna, Kalle 2003. Petserimaa. Petserimaa integreerimine Eesti Vabariiki 1920-1940. [Pechory: Integration of Pechory Region in the Republic of Estonia 1920-1940.] Loodus. Aeg. Inimene. Tallinn: Eesti Entsüklopeediakirjastus.

Masing, Uku 1995. Eesti usund. [Estonian Religion.] Tartu: Ilmamaa.

Orfinskii, Viacheslav P. 1992. Narodnoe dereviannoe kul'tovoe zodchestvo Rossiiskogo Severa: istoki razvitiia. [Popular Cultic Timber Architecture of the Russian North: the Sources of Development.] In: V.P. Orfinskii (ed.) Narodnoe zodchestvo. Sbornik nauchnykh trudov. Petrozavodsk: PetrGu, pp. 32-62.

Pae, Taavi 2008. Põhi ja lõuna Eesti kultuurigeograafias. [North and South in Estonian Cultural Geography.] In: Tartu Ülikooli Lõuna-Eesti keele- ja kultuuriuuringute keskuse aastaraamat, VII.Tartu:TÜ Lõuna-Eesti keele- ja kultuuriuuringute keskus, pp. 79-91.

Pajusalu, Karl; Hennoste, Tiit; Niit, Ellen; Päll, Peeter \& Viikberg, Jüri 2002. Eesti murded ja kohanimed. [Estonian Dialects and Toponyms.] Tallinn: Eesti Keele Sihtasutus.

Panchenko, Aleksandr A. 1998. Derevenskie sviatyni Severo-Zapada Rossii. Issledovaniia $v$ oblasti narodnogo pravoslaviia. [Rural Sanctuaries of the North-West. Studies in the Field of Popular Orthodox Christianity.] Sankt Peterburg: Aleteia.

Paulson, Ivar 1966. Vana eesti rahvausk. [Old Estonian Folk Religion.] Stockholm: Secret. 
PGV 1864 = Poklonenie sosne. [Worship of a Pine Tree.] In: Pskovskie gubernskie vedomosti, 1864 g. No. 24.

Plaat, Jaanus 2001. Usuliikumised, kirikud ja vabakogudused Lääne- ja Hiiumaal: usuühenduste muutumisprotsessid 18. sajandi keskpaigast kuni 20. sajandi lõpuni. [Religious Movements, Churches and Free Congregations in West Estonia and Hiiumaa Island: Changes in Religious Societies from the Mid-18th Century to the End of the 20th Century.] Tartu: Eesti Rahva Muuseum.

Põldmäe, Rudolf 1935. Taevakäijad. [Heaven-Goers.] In: Kaleviste mailt. Õpetatud Eesti Seltsi Kirjad, III, Tartu: Õpetatud Eesti Selts, pp. 123-176.

Pärdi, Heiki 2008. 'Talumajandus.' [Farmstead Management.] In: A. Viires \& E. Vunder (eds.) Eesti rahvakultuur. 2nd ed. Tallinn: Eesti Entsüklopeediakirjastus, pp. 75-106.

Radiņš, Arnis 2006. The Area Populated by the Latgallians and the Shifting of its Northern Boundary in the 7th-13th Century. In: H. Valk (ed.) Etnos ja kultuur. Uurimusi Silvia Laulu auks. [Ethnicity and Culture: Studies in Honour of Silvia Laul.] Muinasaja Teadus, 18. Tartu \& Tallinn: Ajaloo Instituut, pp. 129-146.

Remmel, Mari-Ann 1996. Muistendipaigad ja kohalood Meremäe vallas 1994. aasta suvel. [Legend Places and Place Legends in Meremäe Parish in Summer 1994.] In: H. Valk \& E. Västrik (eds.) Palve, vanapatt ja pihlakas. Vanavaravedaja, 4. Tartu: Tartu Ülikool, pp. 41-58.

Remmel, Mari-Ann (ed.) 1998. Hiie ase. Hiis eesti rahvapärimuses. [Hiis Sites. Hiis in Estonian Folklore.] Tartu: Eesti Kirjandusmuuseum.

Remmel, Mari-Ann \& Valk, Heiki (in press). Muistised, pärimuspaigad ja kohapärimus: piirkondlikud ja ajalised aspektid. [Monuments, Legend Places and Place-Related Tradition: Regional and Temporal Aspects.] In: H. Valk (ed.) Muistis, koht ja pärimus. Tartu.

Saareste, Albert 1932. Die estnische Sprache. Tartu: Akadeemiline Kooperatiiv.

Selart, Anti 2002. Liivimaa ja Vene 13. sajandil. Uurimus poliitilisest ajaloost. [Confessional Conflict and Political Cooperation: Livonia and Russia in the Thirteenth Century.] Dissertationes Historiae Universitatis Tartuensis, 5. Tartu: Tartu Ülikool.

Sirp, Indrek 2001. Muistised ja rahvapärimus Muhus. [Archaeological Sites and Oral Tradition on the Muhu Island.] Saaremaa Muuseum. Kaheaastaraamat 19992000. Kuressaare: Saaremaa Muuseum, pp. 19-57.

Tampere, Herbert 1956. Mõningaid eestlaste etnilise ajaloo küsimusi suulise rahvaloomingu valgusel. [Considerations on the History of Estonian Ethnicity in the Light of Oral Tradition.] In: H. Moora (ed.) Eesti rahva etnilisest ajaloost. Tallinn: Eesti Riiklik Kirjastus, pp. 255-277.

Torp-Kõivupuu, Marju 2003. Ristipuud Lõuna-Eesti matusekombestikus. [CrossSigned Trees in South-Estonian Funerary Tradition.] In: Surmakultuuri muutumine ajas: ajaloolise Võrumaa matusekombestiku näitel. Monograph. Tallinna Pedagoogikaülikooli Toimetised. A 22. Humaniora. Tallinn: Tallinna Pedagoogikaülikooli Kirjastus, pp. 91-125.

Troska, Gea \& Viires, Ants 2008. 'Söögid ja joogid.' [Food and Drink.] Eesti rahvakultuur. In: A. Viires \& E. Vunder (eds.) Eesti rahvakultuur. 2nd ed. Tallinn: Eesti Entsüklopeediakirjastus, pp. 264-278.

Truusmann, Jüri. 2002. Petserimaa setud. [The Seto of Pechory District.] Mäetagused. Vol. 19, pp. 176-190. 
Tvauri, Andres 1997. Eesti lohukivid. [Cup-Marked Stones in Estonia.] In: H. Valk (ed.) Arheoloogilisi uurimusi, 1. Tartu Ülikooli Arheoloogia Kabineti Toimetised, 9. Tartu: Tartu Ülikool, pp. 11-53.

Tvauri, Andres 1999. Cup-Marked Stones in Estonia. Folklore: Electronic Journal of Folklore, Vol. 11, pp. 113-169.

Vahtre, Lauri 1989. Keskaegsete maakirikute ja -kabelite nimipühakute kajastumine Eesti rahvakultuuris. [The Names of Patron Saints of Medieval Rural Churches and Chapels in Estonian Folk Culture.] Kleio, 1' 88. Teaduslik-populaarne ajaloo almanahh. Tartu: Perioodika, pp. 38-45.

Valk, Heiki 1995a. Lõuna-Eesti 13.-17. sajandi külakalmistud rahvatraditsioonis ja uskumustes. [The 13th-17th-Century Village Cemeteries of South Estonia in Folk-Tradition and Beliefs.] In: M. Hiiemäe \& M. Kõiva (eds.) Rahvausund tänapäeval. Tartu: EKM FO, pp. 454-471.

Valk, Heiki 1995b. The 13th-17th-Century Village Cemeteries of South Estonia in Folk-Tradition and Beliefs. In: M. Kõiva \& K: Vassiljeva (eds.) Folk-Belief Today. Tartu: EKM FO, pp. 501-509.

Valk, Heiki 2001. Rural Cemeteries of Southern Estonia 1225-1800 AD. 2nd edition. CCC Papers, 3. Visby \& Tartu: Tartu University Press.

Valk, Heiki 2004. Christian and Non-Christian Holy Sites in Medieval Estonia: a Reflection of Ecclesiastical Attitudes towards Popular Religion. In: The European Frontier. Clashes and Compromises in the Middle Ages. International Symposium of the Culture Clash or Compromise (CCC) project and the Department of Archaeology, Lund University, held in Lund October 13-15, 2000. CCC Papers, 7. Lund Studies in Medieval Archaeology, 33. Lund: Lund University, pp. 299310 .

Valk, Heiki 2007. Choosing Holy Places. In: R. Haeussler \& A. C. King (eds.) Continuity and Innovation in Religion in the Roman West. The Journal of Roman Archaeology. JRA Supplementary Series, No. 67. Portsmouth, RI: JRA, pp. 201-212.

Valk, Heiki 2008. Pre-Christian and Christian: Rites at Two Holy Stones in Setomaa, South-Eastern Estonia. In: A.-B. Falk \& D. M. Kyritz (eds.) Folk Beliefs and Practice in Medieval Lives. BAR International Series, 1757. Oxford: Archaeopress, pp. 67-78.

Viires, Ants 2008. 'Tagasivaade.' [In Retrospect.] Eesti rahvakultuur. In: A. Viires \& E. Vunder (eds.) Eesti rahvakultuur. 2nd ed. Tallinn: Eesti Entsüklopeediakirjastus, pp. 449-455.

Vikstrand, Per 2001. Gudarnas platser: Förkristna sakrala ortnamn i Mälarlandskapen. [Gods' Places: Pre-Christian Sacral Toponyms in the Landscape of Lake Mälar Region.] Acta Academiae Regiae Gustavi Adolphi LXXVII. Studier till en svensk ortnamnsatlas utgivna av Thorsten Andersson, 17. Uppsala: Kungl. Gustav Adolfs akademien för svensk folkkultur.

Wiedemann, Ferdinand Johann 1876. Aus dem inneren und äusseren Leben der Ehsten. St. Peterburg: Keiserliche Akademie der Wissenschaften. 